\title{
Incidence o fmicrobial colonization in coronoray care unit
}

\author{
A Spyrou $^{1 *}$, J Triklis $^{2}$, C Panagiotou $^{1}$ \\ From International Conference on Prevention \& Infection Control (ICPIC 2011) \\ Geneva, Switzerland. 29 June - 2 July 2011
}

\section{Introduction / objectives}

Nosocomial infections in patients admitted in coronary intensive care unit (CCU) are frequently caused by potentially pathogen microorganism (PPM). The aim of the present study is 1) to determine the incidence of PPM in patients admitted in our CCU the last year 2) to identify the risk factors for colonization with PPM.

\section{Methods}

Electronic medical records of all patients without previous infection who hospitalized in CCU unit from January since December 2010 were reviewed. During hospitalization, specimens were taken from the nasopharynx, blood and urine cultures and if applicable from the central or peripherals lines.

\section{Results}

49 patients were included in the study with mean age 63,73yrs $(\mathrm{SD}=15.45) .64 \%$ of the participants were colonized with PPM. The most common isolated pathogens were Staph.Epidermidis (36.7\%), Klebsiella Pneumoniae (32.6\%), Pseudomonas Aeruginosa (10.2\%), Candida Albicans (8.2\%) $\kappa \alpha$ ı MRSA (4.1\%). Risk factors for colonization with PPM were found the duration of stay in $\mathrm{CCU}$ (Anova test, $\mathrm{F}=5.008, \mathrm{p}=.004$ ) and the high levels of urea and creatinine (Anova test, $\mathrm{F}=4.502, \mathrm{p}=.039$ ).

\section{Conclusion}

The rates of PPM were significant high. Proper attention should be given in the risk factors that were found to be correlated.

\section{Disclosure of interest}

None declared.

${ }^{1}$ Coronary Care Unit, Onassis Cardiac Surgery Center, Athens, Greece Full list of author information is available at the end of the article
Author details

'Coronary Care Unit, Onassis Cardiac Surgery Center, Athens, Greece.

${ }^{2}$ Emergency Department, Onassis Cardiac Surgery Center, Athens, Greece.

Published: 29 June 2011

doi:10.1186/1753-6561-5-S6-P75

Cite this article as: Spyrou et al:: Incidence o fmicrobial colonization in coronoray care unit. BMC Proceedings 2011 5(Suppl 6):P75.
Submit your next manuscript to BioMed Central and take full advantage of:

- Convenient online submission

- Thorough peer review

- No space constraints or color figure charges

- Immediate publication on acceptance

- Inclusion in PubMed, CAS, Scopus and Google Scholar

- Research which is freely available for redistribution
C Biomed Central 